\title{
Resources and the Life Course: Patterns Through the Demographic Transition
}

Bobbi S. Low and Alice L. Clarke

School of Natural Resources ( $B S L, A L C$ ) and Evolution and

Human Behavior Program (B $S$ L) University of Michigan, Ann Arbor, Michigan

In most mammals, and in the majority of traditional human societies for which data exist, status, power, or resource control correlates with lifetime reproductive success; male and female patterns differ. Because such correlations are often argued to have disappeared in human societies durng the demographic transition of the nineteenth century, we analyzed wealth and lifetime reproductive success in a nineteenth-century Swedish population in four economically diverse parsshes, subsuming geographic and temporal variation. Children of both sexes born to poorer parents were more likely than richer children to die or emigrate before reaching maturity. Poorer men, and women whose fathers were poorer, were less likely to marry in the parish than others, largely as a result of differential mortality and migration. Of all adults of both sexes who remained in their home parish and thus generated complete lifetıme records, richer Individuals had greater lifetime fertility and more children alive at age ten, than others. The age-specific fertility of richer women rises slightly sooner, and reaches a higher peak, than that of poorer women. These patterns persisted throughout the period of the sample (1824-1896). Thus, wealth appears, even during the demographic transition in an egalitarian society, to have influenced lifetime reproductıve success positively.

\section{INTRODUCTION}

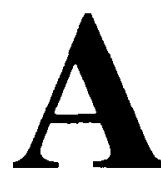

n important question is what, in any species, contributes to greater or lesser lifetıme reproductıve success In most mammals, access to important resources is a strong correlate of lifetime success. Humans are of particular interest In many traditional societıes for which there are data, humans seem to fit the typical mammalian pattern (e g . Chagnon 1988, Betzig 1986, Irons 1979, and others, see review by Low et al 1992) Yet in modern (post-demographic transition) societies the anal-

Recelved December 311991 revised June 18, 1992

Address reprint requests to Bobbi S Low, Ph D. School of Natural Resources and EHB Program University of Michigan Ann Arbor MI 48109-1115 
ysis of this relationship is complicated by temporal variation and lack of appropriate data As a result, several authors have assumed that the demographic transitıon destroyed any relatıonshıp (see discussion by Low et al 1992) Here, we examıne 19th-century Swedish data on the impact of resource access on male and female lifetme patterns and eventual reproduction, through the demographic transition, to examıne the validity of that assumption

The competitive environment into which humans are born is extremely complex, in part due to the long lifetıme over which individuals must respond to changing conditions which will affect themselves and their offspring Demographic transition theory rests on the argument that environmental changes (in most arguments, linked to industrialization) caused famıly sizes to drop Sometimes the arguments are made at the population level (e $\mathrm{g}$. Coale 1986. Wrigley 1985a.b. Viazzo 1990). sometımes at the level of perceived value of children by their parents (Hammel et al 1983) Simpler. more parsimonious arguments exist, which require no group selection. and which are a subset of the well-tested and well-supported behavioral ecological explanations of changes in reproductive output of other species Here. we analyze the relationship between wealth and relatıve reproductıve success throughout the life patterns of people in 19th-century Sweden a population for which excellent records exist through the historic demographic transition from large to small family sizes We examıne longitudinal lifetime data from individuals in four Swedish parıshes, seekıng correlates of reproductive success

Our behavior ecological approach begins with the argument that behaviors which become common and remain so are those that produce reproductive profit for their performers Even for nonhuman species, because the world is often far more complex than one might at first imagine, maximum fertility is not always optımum In fact, "Most successful reproduction" does not necessarily mean producing the most offspring, or even the most survivıng offspring (e g , Lack 1947, 1966, Dawkıns 1982, 1986, 1989, Willıams 1966, Daly and Wilson 1983) The existence of a large "zero success" reproductive group contributes enormously to the variance (ef Falconer 1981), far more than the production of, for example, eight versus six offspring No species produces offspring at its maxımum physıologically defined rate, reproductive success depends not only on production, but also on the investment required to produce viable, competitive, reproductive offspring Thus producing fewer, better-invested offspring, compared to the maxımum physiologically possible, can be, dependıng on environmental conditions, reproductively more efficient Costs and benefits may differ for male and female parents (e g , see Daly and Wilson 1983, Krebs and Davies 1991) This reiterates and extends the "quantity-versus-quality" dilemma first raised by Darwin (1871)

If there is a behavioral ecology of fertility, many patterns of startıng, stopping, and spacing children are possible adaptıve responses to environ- 
mental conditions that vary among societies and across time, rather than non-optımum-because-not-maxımum patterns (see review by Low et al 1992). Behavioral ecological approaches are really cost-benefit approaches that use reproductive as well as economic currencies. Both purely economic and Darwinian views of fertility recognize that social and economic success are important goals affectıng reproductıve decisıons. But those who do not specify such goals as proximate goals (that have over evolutionary time correlated with enhanced reproductive success) make quite different predictions from Darwinians: for example, that it is most rational to produce maximal number of children in traditıonal societıes (e $g$, Handwerker 1986) An evolutionary approach argues that fertility schedules should respond to ecological conditions (e $\mathrm{g}$, Turke 1989, 1990, Blurton Jones 1986, 1987, 1989), and that better- versus worse-off families should respond differently

In preındustrial human societıes, resources and net lifetıme reproductıve success are correlated (Hıll 1984, Chagnon 1988, Betzıg 1986; Boone 1986; Hughes 1986, 1988, Flinn and Low 1986, Voland 1990, Voland and Engel 1990, Low 1989, 1990a,b, 1991) Human patterns, though, can vary greatly, and show many historical particulars There seems to be a stronger association between status or resource control and reproduction among traditional societies than among modern, post-transition societıes, thus data from the demographic transition are important

\section{Hypothesis and Predictions: What Influences Individual Reproductive Lives?}

Here, then, we will ask, in the most synthetıc manner, about lifetıme reproduction and wealth, about the survivorship and fertility of richer versus poorer individuals in a society entering the demographic transiton Did the survivorship of children of richer versus poorer parents differ? Were these chıldren more or less likely to leave the parısh as chıldren? As adults, were richer versus poorer individuals more likely to leave the parish? As adults, if they stayed, were they more or less likely to marry' Did the age-specific fertility of richer versus poorer women differ? $\Lambda$ vallable resource levels should influence fertility, mortality, and migration in specific ways Abundant resources should be associated with high fertility and low out-migration from the region, reduction in resources should be accompanied by lowered fertility and greater out-migration

The hypothesis that resources contribute to enhanced survivorship and reproduction generates the following predictions

[1] Chıldren of richer families should survive better to adulthood (here, as earlier, defined as reachıng age 15)

[2] Children of poorer families, as their parents seek better opportunities elsewhere, should be more likely to move from the home region (parish) before reachıng age 15

[3] Of those individuals reachıng maturity (age 15) in the parish, poorer 
indıviduals, again seekıng better opportunities elsewhere, should be more likely to leave the parish before marrying Theory suggests that women may typically leave the parish in order to marry, while men may be more likely to leave for occupational reasons (Clarke and Low in press) but we cannot yet test for this difference

[4] Of adults remaınıng in the parısh, rıcher indıviduals should be lıkelıer to marry than poorer

[5] Of individuals for whom we have full reproductive records, wealthier individuals should show higher lifetıme fertılity (NBC. Low 1989, 1990a) and greater completed family size $\left(\mathrm{RS}_{10}\right.$, Low 1989 , 1990a) than poorer individuals

[6] Women married to wealthier men should show higher age-specific fertility than poorer women

\section{THE SAMPLE AND METHODS}

Our data from the 19th century, in four geographically separated parishes (Tuna, Locknevi, Gullholmen, and Nedertorneå), follow, from 1824 to 1896 (when records end for privacy reasons), the lifetımes of descendants of a cohort of men married in the parishes between I824 and 1840 The sample includes longitudinal (lifetıme) data for all indıviduals sex. date of birth, age at marriage, best occupation, date of record loss, type of record loss (death, emigration), dates of birth of all children, and comparable data for those children (see Low et al 1991)

The four parishes differ in economic and ecological conditions (described below) We choose this time and these places because excellent records exist, and the demographic transition is of considerable theoretical interest with regard to the issue of numbers versus investment in off spring In previous papers, we have treated specific comparisons for individual parishes involving the influence of occupational status (Low 1989, 1990a, Low and Clarke 1991, Low et al 1991). land (Low 1990)a), and extrinsic economic fluctuations (Low and Clarke in press), the interaction of these with other forces such as mother's age and but th order (Low 1991). how these influence individual reproductive success (Low 1989. 1990a. 1991. Low and Clarke 1991. Low et al 1991) and probabılity of migration (Clarke and Low in press) and the variation in impact across tıme and space (Low et al 1991. 1992)

Here. new analyses summarize how 19th-century Swedish life courses varied as a result of resources, we seek the most general possible answer It is difficult to elucidate relationships that vary both temporally and spatrally, hence we have structured our analyses to make comparisons by decade and by parish (below) Doing this allows us to analyze the relationship between resources and lifetıme reproduction through the changing economic and social times of the demographic transition. and in parishes of very dif- 
ferent base fertility levels Thus we can follow sometımes subtle relationships through the changing times of the 19th century

\section{Nineteenth-Century Sweden}

Nineteenth-century Sweden was largely agricultural, with emerging protoindustrialızation (Mendels 1981) geographically scattered market activity which involved transforming raw materials into "made" commodities, but with a large part of the labor force working part-tıme or at home The family could function as a form of economic enterprise (see also Flandrin 1979 , Habakkuk 1955) Such proto-industrialization tended to develop in regions combining an underemployed, land-poor population, with access to urban markets (e g , Tilly 1978) In Sweden it is probably related to land enclosure and inheritance changes during the nıneteenth century (Jorberg 1972, 1975) Marriage in Sweden followed the "European" pattern (Hajnal 1965), with women marryıng for the first tıme in their early- to mid-twentıes, and men in their late twenties At marriage the new couple typically set up their own independent household, a relatıvely high proportion of individuals never married (Low 1989, 1990a, Low and Clarke 1991)

From 1686 to 1810 , the nobility practiced "fideıcommiss," or male primogeniture. with the constraint that the eldest son must contınue the practice (Malmstrom 1981, Inger 1980) Untıl 1845, sons inherited twice as much as daughters, after that date, daughters had equal inheritance rights, although in practice sons had first choice of the land and goods which were to be their inheritance, and sons could purchase their sisters' inheritance from them (Lo-Johansson 1981, Inger 1980) This meant that disputes occasionally arose over the value of the exchanged inheritance items. purchasing needed land from a siblıng could prove economically onerous, but also sıblıngs sometımes complained that they did not receive fair value (not uncommon elsewhere in Europe, see Habakkuk 1955) Even after the shift from fideicommiss, and even after establıshment of legally equal inheritance rules for both sons and daughters, inheritance biased by birth order was often evident (see Gaunt 1987, Low 1989, 1990a), and a bias toward the first son was perhaps more evident in the northern areas Legal agreements in which a father ceded his land to one (usually the eldest) of his sons before his death, typically in return for room, food, and certain other rights, were common But as Gaunt (1987) noted, durıng the nineteenth century the payments delivered to the retırıng father increased in size, and receiving a farm became an economic burden Indeed, default was common, and contemporary jokes abounded about arsenıc as "retırement medıcıne" (Gaunt 1977, 1983) Thus, there probably existed some tension both withın and between generations over resources

Access to resources was important to men's reproductive success in 19th-century Sweden, although the particulars differed among the parishes Individuals might be better off because they owned land (Low 1990a, Low 
and Clarke 1991, in press), because they had higher status or more stable occupations (Low 1989, Low and Clarke 1991, in press), or sımply because they were first-born in a family, and therefore had higher reproductive value to the parents (e g. Fisher 1958, Keyfitz 1985) A man's best occupation was associated with differential likelihood of marrying (Low and Clarke 1991), married men had ignıficantly more (acknowledged) chıldren than unmarried men, and significantly more children surviving to age ten (I ow 1990a, Low and Clarke 1991) Richer men married younger (higher reproductıve value. Fisher 1958) women than poorer men, and had larger families (Low 1989. 1990a. Low and Clarke 1991) Where land ownership records were avalable, we found that landowners were more likely to marry than non-landowners, and they marred younger women (Low 1990a) Married men who owned land had more children than married men without land (Low 1990a) For women. age at marriage was the most important determınant of lifetıme reproduction (Low 1989, 1990a. Low and Clarke 1991), women who married richer men tended to marry earlier

Females were more likely to migrate than males, both as children and as adults, again, particulars differed among the parıshes (Clarke and Low in press) Among adults, married people were less likely to migrate than were single individuals Much of the patterns reflected the importance of resources People in Locknevi (in which resource constriction occurred, Low 1989, Low and Clarke 1991) were most likely to migrate Children of farmers, with a possibility of inheriting land, were the least likely to move (Clarke and Low in press) Individuals born late to large familıes were more likely to migrate than those born before them (Clarke and Low in press) We do not know the ultımate influence of migration on the reproductive lives of dispersers (cf Easterlın et al 1978)

The four parıshes we examıned are scattered from south to north in Sweden, and vary greatly in their economic bases (see Low and Clarke 1991 for map)

Gullholmen. Gullholmen is an island parish Here most people earned a livelihood by fishing. and the catches could vary considerably trom year to year The small population of Gullholmen rose steddily dus ing the nineteenth century (Swedish Demographic Database, unpublished statistics) but was always less than 1000 individuals (Low and Clarke 1991) Nonetheless, the island was small, and density was the highest of any parish Perhaps related to the uncertanties of fish catches, and the costs associdted with commercial fishıng, people married late Nonetheless, the lifetıme family size of married individuals was the highest of the four parishes (Low and Clarke 1991)

Locknevi. In Locknevı Parısh. in Smáland. geography imposed constrants on farming (Gerger and Hoppe 1980) only in the central valley were there fields of sufficient fertility tor farming A small iron-works in the southwestern part of the parish provided supplemental income for some taimers 
untıl the 1880s. Population growth stagnated in the later part of the 19th century At the beginning of this study, a few very large landholdings existed in Locknevi, controlled by a small number of individuals Agricultural dayworkers found employment here The amount of cultivated land increased in the 19th century However, large estates were divided and sold off (Gerger and Hoppe 1980) and their rich owners moved out of the parish, so that landholdıngs became progressively smaller Some newly cultıvated holdıngs were in agriculturally marginal land Thus in Locknevı Parısh durıng the period of this study, resource holdings shifted from being relatively uneven with some very large holdings to more even but more restricted holdings

In Locknevı, there was a substantial wage-dependent agricultural working class, the statare Purchasing power, as reflected by the number of days' work required to purchase a hectoliter of rye, a hectoliter of fish, and a kılogram of butter, varied more than in Tuna Perhaps, except for the few richest families, people's economic lives were more uncertain in Locknevi Famıly patterns in Locknevi also showed more variance than in Tuna, as economic times got worse, then better, family sizes fell, then rose (Low and Clarke in press)

Tuna. The population of Tuna Parish, in Medelpad, rose from approximately 1200 in the early 19 th century to approximately 3300 in the late 19th century (Low and Clarke 1991) Tuna was largely a farmıng parısh, though forest and mınıng industries were also present in the early 1800s Many men worked in the iron foundry (Matfors Bruk) as well as farmed (see Ostergren 1990; also Sundin and Tedebrand 1981) Tuna experienced rapid industrialIzatıon from 1850 onward (Norberg and Rolén 1979) Matfors Bruk closed In 1879, and reopened in the mid 1880s Tuna Parish possessed a more diverse economy (forestry, ironwork, mixed crop agriculture) than Locknevi Perhaps as a result of this diversity, and the avallability of non-market alternatıves (huntıng, fishıng), population measures dıd not correspond with measured economic fluctuations in Tuna Parish, while they did co-vary in Locknevi (also see Jorberg 1972, Sundın 1976) In Tuna, there was also no difference in reproductive response to economic conditions, between richer and poorer individuals, or landowners versus non-landowners Landowners, however, had larger families no matter what the tımes Perhaps land ownershıp provided a buffer agaınst hard tımes, over and above the non-market alternatıves Interestıngly, landowners' famılıes not only were larger, but showed less variance (Low and Clarke in press) than those of non-landowners.

Nedertornea. Nedertorneå, the most northern parısh, was a farmıng parısh, land was generally of poor quality Throughout the first half of the nineteenth century, the Finnish habıt of feedıng infants on cow's mılk rather than nursing was common (Brandstrom 1984) This practice has been suggested to have negative impact on infant survival (Lithell 1982), and indeed, infant 
survivorshıp in Nedertornea was lower than in the other three parishes (Low 1991) In the mid-nıneteenth century, the central Swedish government establıshed a bureaucratıc outpost in Haparanda. resultıng in a more varıed economic environment The population of Nedertornea rose steadily durıng the mmeteenth century (Swedısh Demographic Database, unpublished statistics) (Low and Clarke 1991)

\section{Comparisons}

An individual can only control some of the factors influencing his or her reproductive life In this study, of extrinsic factors, some were related to the family into which one was born, others to an external, broader economy Familial factors, such as the occupation(s) of one's father, whether or not he owned land, and one's order of birth into a family also influenced the pattern of an individual's life Factors external to the family, such as the basis of the regional economy (in this sample, forestry, dgriculture, minıng, fishıng, etc $)$ and other resource fluctuations, could also influence an indıvidual's reproductive success

People in the four parishes responded somewhat differently to extrinsic fluctuations, and these differences in reproductive response are probably related to ecological and resource differences In many areas in southern Sweden, single crops domınated the economy Rye and corn were major crops, corn was particularly labor-ıntensıve Bad harvests created real hardships, reflected in prices and purchasıng power In the north, barley was an important grain crop, but agriculture was more mixed. and was consistently supplemented by fishıng and forestry Thus, fallure of any particular crop was likely to have less impact on people's lives Harvest and price information alone are insufficient reflections of conditions in such areas (see Low and Clarke in press) Sundın (1976), analyzing theft and poverty in Sweden, found that famınes and high food prices were good predictors of theft in the counties relyıng on one principal agricultural crop However, in "mixed" countıes (e $g$, Kalmar, whıch includes Locknevı Parısh), the correlation was weaker In the northern "forest" countıes (e g, Vasternorrland, which includes Tuna Parısh), forestry and ıronworks as well as huntıng and fishing supplemented agriculture, yıeldıng a diversıfied economy In these counties, Sundın found no significant relationshıp among crop yıelds, cost-of-lıving indices, and theft rates All of these differences dre important, particularly in the examination of historical and parish-specific patterns

To explore the effects of wealth on lineage success in this society most broadly, we here examıne patterns in the most general context Because we want to ask about better-versus-worse strategies, in terms of lifetıme reproductive success relative to the reproductive competitors present at the tıme in each parish, we need to subsume temporal and spatial differences without ignoring them Our methods are described in detall elsewhere (Low and Clarke 1991, Low 1991, Clarke and Low in press) Here we will sum- 
marize pertınent information only briefly As in our earlıer analyses, we will define wealth by father's wealth for children and by own status for adult men and father's or husband's status for adult women Because women seldom if ever exceeded their father's wealth in this society, unless they marned hypergynously ( 1 e , "up"), we used father's wealth for unmarried and husband's wealth for married women

Reproductive patterns varied in tıme and among parıshes (I ockridge 1983, Low and Clarke 1991, Low et al 1992, see also Røskaft et al this volume); to make general statements for all of the parishes, we must take that into account In one parish (Tuna) we had land ownership information (Low 1990a), in others we had only occupational information (Low 1989. Low and Clarke 1991, Low et al 1992) To make broad comparisons possible without ignoring this variation among parishes and through time, we compare each individual's wealth as "richer" (owned land and/or had occupational status of upper-middle class, lower-middle class, or bonder $[=$ farmer $]$ ) versus "poorer" (occupational status of torpare $[=$ cottar $]$ or proletariat and no land ownershıp record) We compare each adult indıvıdual's lifetıme reproduction to the median for [1] all individuals reaching "maturity" (23 years) in any decade in any parısh, and [2] all individuals marrying in each decade in each parish Thus we compare any individual's lifetime reproduction to the median for his or her parish and decade of maturation or marriage, as appropriate Statistical analyses compare the entıre sample, stratıfyıng by richer-versus-poorer, thus reproductıve measures are compared for richer versus poorer individuals, with comparisons stratıfied by parish and decade

We integrate these data into a picture of IIfe prospects for people born in different conditions, and we relate these patterns to the general problem of resources, family decisions, and demographic transitions In this way we hope to take regional differences and historical particulars into account, but not to be distracted by them in this analysis

\section{PATTERN IN LIFETIMES}

These predictions are as general as we can make them If the correlation between wealth and reproductive success holds even in a society as monogamous and egalitarian as 19th-century Sweden, and even durıng the demographic transition there, we consider it powerful evidence of the strength of the relationshıp Let us examıne, then, the lifetıme patterns of individuals as they are influenced by wealth and resource control

\section{Wealth and Survival}

Because male and female mammals typically show very different survivorshıp curves, and this sample from Sweden has proved no exception (Low 
et al 1991, Low 1991), we examıne the survivorshıp of sons and daughters separately Both sons $\left(W_{1}\right.$ lcoxın $\left.=608, \mathrm{~d} f=1, p=001\right)$ and daughters (Wılcoxın $=117 . \mathrm{d} f=1, p=00006$ ) survived to age 15 better in wealthier families (Prediction 1, Fig la) In both wealthier and poorer families, as in our previous tests (Low et al 1991) we found no evidence of significant under-valuing of daughters among wealthier or landed famılıes (cf Voland and Engel 1990, who did find such a pattern in German villages) That is, withın both richer and poorer famılies, daughters survived better than sons

These results are of interest in light of Sweden's leadershıp in egalitarian health care and support (e g, Brandstrom 1988) In Nedertorneå, the results were particularly strıkıng (Brandstrom 1984. Low and Clarke 1991. Low et al 1991) Infant survivorship was low, due to the habit of feeding intants cows' milk (which often was contamınated) rather than breast-feedıng them (Brandstrom 1984) The central Swedish government carly in the nineteenth century moved upper-level civil servants to the outpost town of Haparanda, to shore up the local economy (e $\mathrm{g}$, Brandstrom 1984), and in the 1840s, a doctor came to Haparanda, begınnıng a campaign to reınstitute breast-feeding He worked mainly with upper-middle class families and in the town of Haparanda rather than the surroundıng countryside, and Brandstrom (1984) found significant fertility and survivorship differences both with class and with residence (town versus countryside)

Brandstrom's results confirm the value of seekıng general, broad trends hut also analyzing at a finer level to discern the historical and social complexitıes In Brandstrom's correlatıons, residence (which correlated with breast-feedıng most strongly) was even more important than status That is, the poor people in the town of Haparanda who worked for the wealthy, also began, through contact with their employers, to breast-feed, thus their infant survivorship improved more rapidly than that of the farmers Similarly, Sundin and Tedebrand (1981) found that infant mortality rates among farmers versus factory workers varied more with social factors than simply with wealth As infant and child mortality fell during the 19th century in Sweden, it frequently fell first among the middle class and proletariat (perhaps for reasons similar to those of Brandstrom's), and later among craftsmen's famllies, who tended to be wealthier than proletarıat (Nılsson and Sundın 1991)

Once individuals reached age 15 , and were typically independent of their natal families in many ways, the pattern became more complex, results were not statistically significant Richer women (Wilcoxın -235 , d f $-1, p-$ 0 13) and richer men (Wilcoxın $=227, \mathrm{~d} f=1, \mathrm{p}=0$ 13) survived slightly less well to age 55, hut then lived longer than poorer men and woman (Fig. 1b) Elsewhere (Low 1991, Low and Clarke 1991) we have noted more specific adult survivorshıp differences associated with occupational risk. Here we find that despite all variation, throughout life, though with declinıng force, wealth influenced survivorship of both males and females. 

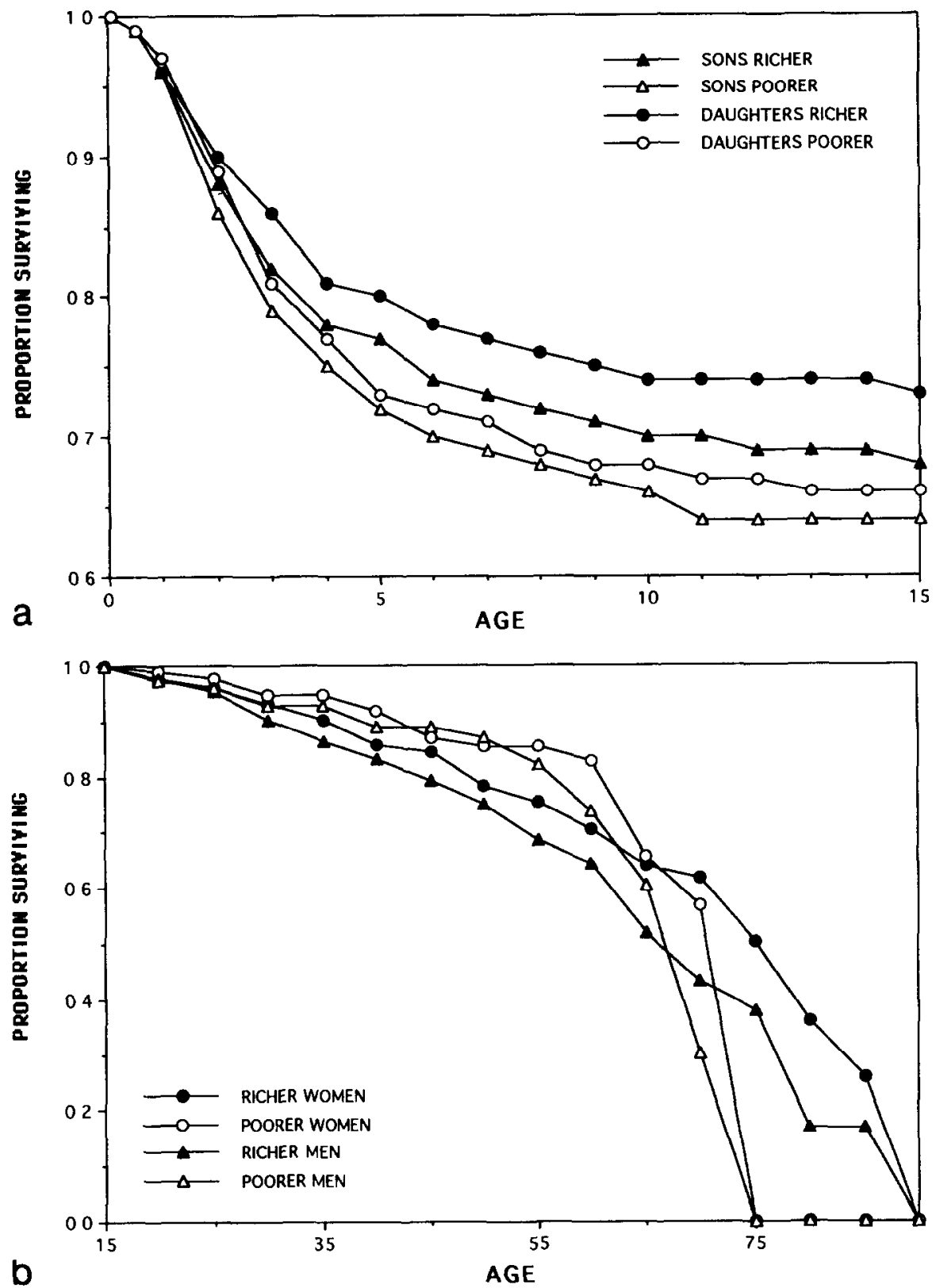

FIGURE 1. (a) Survıvorshıp to age 15 was greater for chıldren born to rıcher parents than to poorer parents, within-sex comparisons were significant for both sexes (see text) (b) After reaching age 15, poorer individuals who stayed in the parısh had margınally better survivorshıp to age 55 than richer indıviduals, but then died earlier Patterns were complicated by the risks of particular occupations, childbearing, etc 


\section{Wealth and the Likelihood of Leaving}

Children ( $<$ age 15) had a relatively low probabilıty of leaving their parısh of birth Those who did move. obviously, left with their parents Children's migration was dependent, then, on parent' probability of migration People with children were less likely to move than those without children (Clarke and Low in press) Their probability of movement correlated with resources (Prediction 2)

Once individuals reached age 15, many were financially independent, in the sense of living independently and relyıng on their own income Elsewhere (Clarke and Low in press) we have suggested that resource control ability may be important, especially for men, in decisions about whether to ledve the parısh Women whose fathers were nicher were, lıke ncher men. far likelier to remain in the parish $\left(n=1557, \mathrm{~d} f=1, X^{2}=1298, \mathrm{p}=\right.$ $00003)$ Richer men (including all landowners) were far lıkelıer to remain In the parish of their burth $\left(\mathrm{n}=1599, \mathrm{~d} \mathbf{t}=1, \mathrm{X}^{2}=1825, \mathrm{p}<000001\right)$ than poorer men (Prediction 3) Complexitıes described in Clarke and Low (in press) suggest that land ownershıp was the domınant resource influencing philopatry Children of the upper-middle class and lower-middle class were actually more likely to leave their parish of birth than were farmers We believe that the movement of these classes may be related to the "liquidity" of their resources and skills, proving beneticial when conditions became very poor at home relatıve to those elsewhere (Clarke and Low in press)

\section{Wealth and Marriage}

Independent of the probability of leaving is the probability of marrying. individuals may leave as married or single, or stay and marry or not Of all individuals born. richer men $\left(\mathbf{n}=1599\right.$, $\mathrm{d} f=1 . \mathbf{X}^{2}=763, \mathrm{p}=000057$ ), and women whose fathers were richer $\left(\mathrm{n}-1557 \mathrm{~d} f-1, \mathrm{X}^{2}-501, \mathrm{p}\right.$ $=0025$ ) were likelier to marry than their poorer counterparts (Prediction 4) Carlsson (1977) simılarly showed that daughters of landless Swedish men were less likely to marry than daughters of landowners, and that among nonlandowners, daughters of manual workers were less likely to marry than daughters of wealthier non-landowners Simılarly. Sundın (1989) found that daughters of Swedish landowners were more lıkely to marry than daughters of landless men, and that among daughters of iron foundry workers daughters of the more skilled workers were more likely to marry than others

Examining only those who remaned in the parish for their entıre adult lives highlights an interestıng sex difference Of men who remained in the parısh, richer men were likelıer to marry than poorer men $(\mathrm{n}=1058 \mathrm{~d} f$ $\left.=1, X^{2}=601, p=001\right)$ Of women who stayed, their father's wealth showed no pattern with their lıkelıhood of marrying $\left(\mathrm{n}=893, \mathrm{~d} \mathrm{f}=1, \mathrm{X}^{2}\right.$ $=079, \mathrm{p}=037$ ) 


\section{Wealth and Lifetime Fertility}

Of all men who remained in the parısh of their birth, richer men had more children (NBC. $\mathrm{n}=1043, \mathrm{~d} f=2, \mathrm{X}^{2}=1084, \mathrm{p}=0$ 004), and margınally more children alive at age ten $\left(\mathrm{RS}_{10} \mathrm{n}=1043\right.$. $\mathrm{df}=2, \mathrm{X}^{2}=426, \mathrm{p}=$ 0 118) than poorer men (Prediction 5) Similarly, of all women who stayed their whole lives in the parish of their birth, richer women had more children (NBC $\mathrm{n}=594, \mathrm{~d} f=2, \mathrm{X}^{2}=1349, \mathrm{p}=0001$ ), and more children alive at age ten ( $R S 10 n=594, d f=2, X^{2}=1008, p=0007$ ), compared to the medians for all adults reachıng maturity in the same decade in the same parish

In our by-parısh analyses. in which we did not compute the median reproductive patterns by decade, we observed these differences for men, but were unable to see them for women, because of remarriage patterns, sample size, and withın-parish (e g, temporal) varıation, which swamped the differences (Low 1989, 1990a, Low and Clarke 1991 in press) Here we find the impact of wealth on fertility is also reflected by the age-specific fertility of richer versus poorer women richer women's fertility rises faster and remains higher than poorer women's fertılity throughout their reproductive lives (Prediction 6, Fig 2) Note that the sample in Figure 2 is not women whose entire reproductive lives are under observation

The impact of resources is less when one compares only married in-

FIGURE 2. Women married to richer husbands (in spite of interparish differences, Low and Clarke 1991) had higher age-specific tertility throughout their reproductive lives

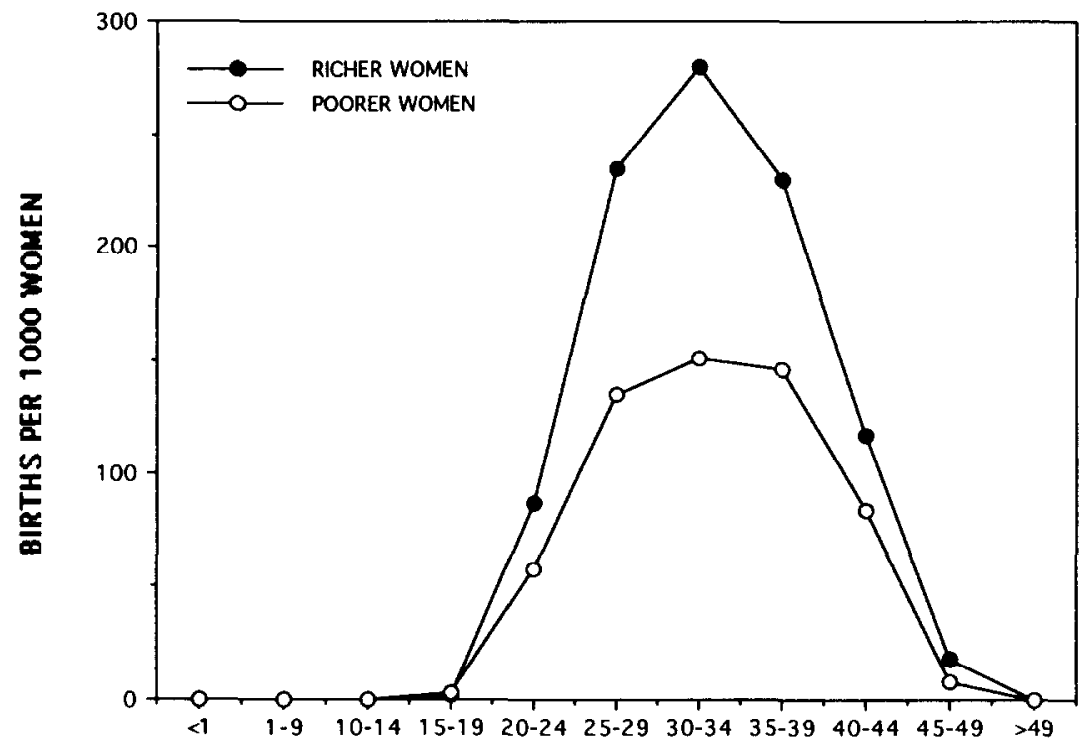

AGE 
dividuals who remained in the parısh, perhaps reflecting the fact that migration is an option open to individuals not marrying or establishing successfully in the parish of married men who stayed, lifetıme fertılity was greater for richer men (NBC $n=872, \mathrm{~d} f=2, \mathrm{X}^{2}=683, \mathrm{p}=003$ ), but family size was not (RS10 $n=872, \mathrm{~d} f=2 . X^{\prime}=108 . p=058$ ) Because survivorshıp of children born to richer parents was greater. we suspect this means that families who werc not prospering left the parish at a greater rate (even though in general individuals with children were less likely to leave) In the restricted sample of marned women who stayed, there was no difference with (husband's) status in either the number of children born (NBC $\left.\mathbf{n}=434 . \mathrm{d} \mathbf{f}=2, \mathbf{X}^{2}=278, \mathrm{p}=025\right)$, or children alive at age ten $\left(\mathrm{RS}_{10}\right.$ $\mathbf{n}=434, \mathrm{~d} f=2 . \mathbf{X}^{2}=029, \mathrm{p}=0$ 87) (see also Low 1989. 1990a, Low and Clarke 1991, Low et al 1991) As we have noted elsewhere, men's and women's patterns diverge in this sample sometimes because the women in this sample are not necessarily married to the men in this sample, they are the sisters and daughters of these men

\section{Wealth and Life Patterns}

Wealth, viewed simply as "ncher" versus "poorer." thus influences the life patterns of both males and females (Fig 3) Above. we have discussed individuals as "richer" or "poorer," "married" or "never married," without discussing how likely they were to reach any particular status Some of the statistical tests we used above do not reflect the fact that one's probabilities (e g, of marrying) may change throughout life the probability of marrying for a daughter born to a poor father is different at birth, if she survives and remains in the parish to age 15 , and if she remains in the parish after age 15 Figure 3 highlights in bold lines the lıkelıest paths followed by sons and daughters of rich and poor men to greater (above-to-median marital fertility) or lesser (below-median fertılity for all adults) reproduction Here, our goal is to emphasize that within existing variation there were still dominant patterns

Females (Fig 3d, b) Daughters of poor fathers were about 10\% more likely to die or migrate from their parish of birth before the age of 15 than were daughters of rich men Women were also more likely to leave as adults if born to poor fathers Overall, daughters of richer men were more likely to remain in the parish and marry (above), however, of the women who stayed in their parısh of birth to reproductive age, daughters of both rich and poor men were equally likely to marry ( $\left.F_{i g} 3 a, b\right)$ The likely remainıng life-paths for married women and unmarried women differed, dependıng on whether they were born to poor or rich fathers of women who married, virtually all women $(98 \%)$ born to poor fathers married men who were poor, while $77 \%$ of women born to rich fathers married rich men Married women's fertility was compared to that of other women in the same parish of birth 


\section{A. Females born to poorer fathers}

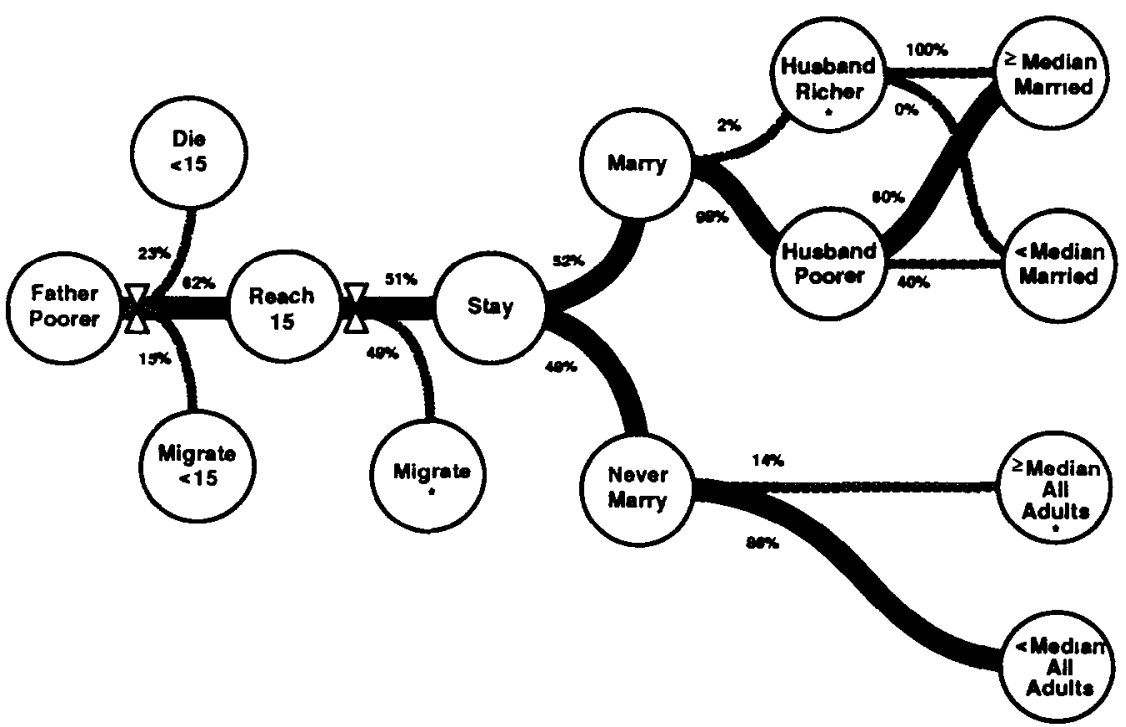

FIGURE 3. Some paths (heavy lines) were more likely than others for individuals born to richer or poorer fathers Reproductive comparisons are relative to all adults who reached age 23 in the same decade in the same parish for non-married individuals, and relative to all individuals marrying in the same parısh during the same decade for married individuals Strong within-sex differences are highlighted by asterisks Extrinsic factors (indicated by valve symbols) could matter, for example, in probability of out-migratıng or marryıng (see also Low 1989. Clarke and Low in press) These greatest-likelihood pathways smiply track, for all individuals born in the sample, the percentage at each comparison point who follow one or another fate This is a visual representation, and the numbers dimınish at each juncture. so the percentages will not always suggest the results of the statistical analysis $(\mathrm{e} \mathrm{g}, \mathrm{a}$ statıstical difference may be great, while the percentage is small, or vice versa, because numbers are large or small) (A) A daughter born to a poorer father was more likely than her richer cohorts to leave the parısh before age 15, if she stayed, she was about equally likely to marry She was overwhelmıngly likely to marry a poorer husband Though her fertility could be great $(33 \%$ had the median number of children for their decade of marnage and parish), her sons were likcly to leave the parish, and, if they stayed, to do poorly reproductively if she did not marry, there was an $86 \%$ chance she had fewer than the median number of children for all adults 


\section{B. Females born to richer fathers}

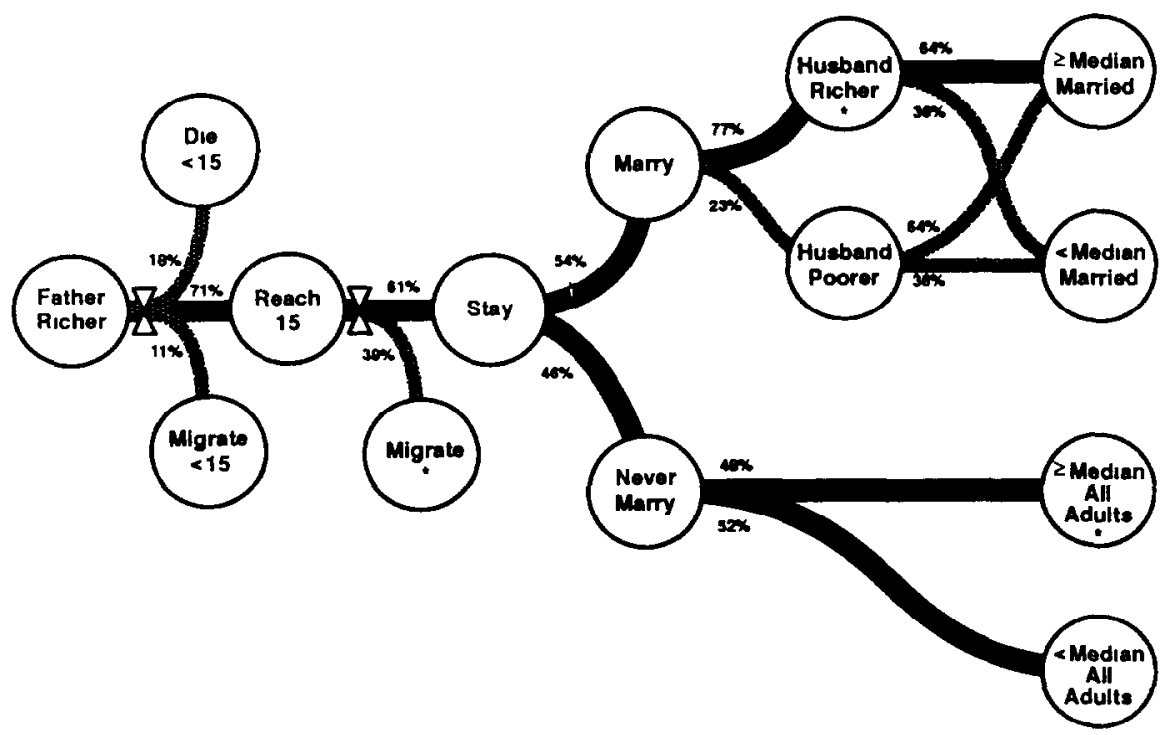

\section{Males born to poorer fathers}

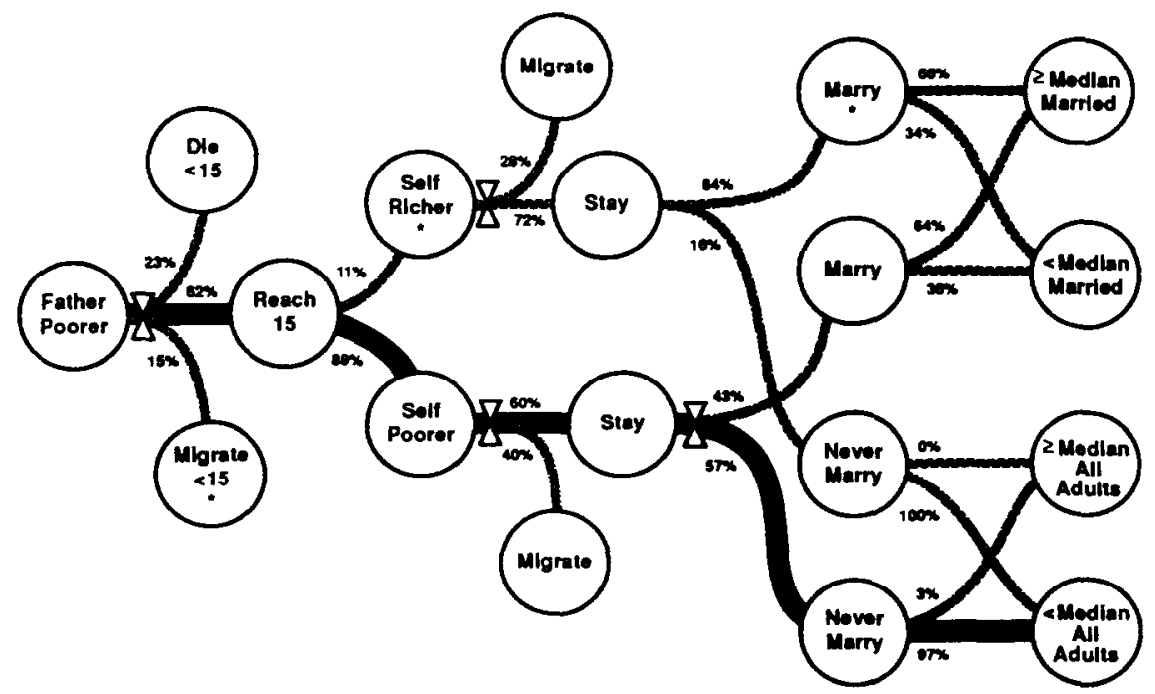

FIGURE 3 (Continued) (B) A daughter born to d richer father had a higher chance of remaining in the parish, and an equal chance of marrying If she married, there was a $77 \%$ chance her husband was richer If she did not marry, there was a $48 \%$ chance she would have greater than or equal to the median number of children for all adults (C) Sons of poorer fathers were likelıer to leave the parısh before age 15 . compared to sons of richer fathers $(15 \%$ versus $8 \%)$. for sons of poorer men who stayed, there was an $89 \%$ chance they would be poor, and a $40 \%$ chance they would migrate out as adults Such men who stayed were likely never to marry $(57 \%)$, and $(97 \%)$ have fewer than the median number of children compared to all adults 


\section{Males born to richer fathers}



FigURE 3. (Contunued) (D) Sons born to nicher tathers, once they reached age 15 , had an excellent chance of becoming richer themselves $(91 \%)$ These men were more likely to stay as adults (69\%) Theır chance of marryıng was about $48 \%$ Those who married tended to have the median or greater number of children compared to other married individuals (59\%), those who did not marry were lıkely to have fewer than the median number of children, compared to all adults $(55 \%)$

who married in the same decade Fertılity of unmarried women was compared to all adult females in the same parish of birth who reached age $23 \mathrm{in}$ the same decade Women who were born to poor fathers and never married were far more likely $(86 \%)$ to have fewer than the median number of children born to all adult women Daughters born to rich men and never married nonetheless had a $48 \%$ chance of having greater than the median number of children, suggestıng that illegitımate births occurred at higher rates among the rich (cf Low and Clarke 1991, who found illegitımacy rates from $2 \%$ to $7 \%)$

In summary, women born to rich fathers were more likely to survive to adulthood and stay in their parish of birth than were women born to poor fathers While all daughters stayıng had about the same probability of marriage, their paths nonetheless diverged daughters of poor fathers married poor men, and daughters of the rich married rich men Fertılity of unmarried women was related to father's status, daughters of poor men were likely to have fewer than the median number of children relatıve to all adults

Males. (Fig 3c, d) Males born to poor fathers were 7\% more likely to migrate before age 15 than were sons of rich men (Fig $3 \mathrm{c}$, d) As adults, sons of rich men were very likely $(91 \%)$ to become wealthy themselves, 
while sons of poor men were lıkely to stay poor $(89 \%)$ As adults, poor sons of rich men were $6 \%$ more likely to migrate than poor sons of poor men (see Clarke and Low in press for a discussion of the influence of skills and 11quidity of resources on migration)

Of men who stayed in their birth parısh, probability of marrying varied with own and father's status Poor sons of poor fathers were most likely to remain unmarried $(57 \%), 97 \%$ of such poor, unmarried men had fewer than the median number of children Fertility comparisons for men were done in an analogous manner to those for women Rich sons of rich fathers had an approxımately equal chance of marryıng or not (48\% versus $52 \%$ ), and once married had a $59 \%$ chance of having the median or greater number of children Rich sons of nich fathers who did not marry were, lıke poor sons of poor fathers, more likely to have fewer than the median number of children Although $97 \%$ of poor sons had this fate, only $55 \%$ of rich sons did

Two less likely but interestıng paths also occurred Most dramatically, the few men (11\%) who were able to attain wealth even though born to a poor father had an $84 \%$ chance of marryıng, and once married, a $66 \%$ chance of having at least the median number of children On the other hand, poor sons of rich fathers did not fare as badly as the poor sons of poor fathers Poor sons of the rich still had a greater probability of marryıng $(54 \%$ versus $46 \%$ ), and once married had a $74 \%$ chance of having at least the median number of children Perhaps these men benefited from their relationshıp within a wealthy family in ways not measured by their occupational status

Thus, the most likely life-paths for men varıed Sons born to poor fathers were most likely to remain poor themselves, never to marry, and to have fewer than the median number of children Sons of rich men were most likely to become rich themselves Their chances of marrying or not were about equal, if they married, they were lıkely to have at least the median number of children, if they did not marry, they were likely to have fewer than the median number

Figure 3 reflects likelıhoods through individual lifetımes, but these patterns may translate into population trends For example, a man's lifetıme fertılity was influenced by his, and his father's, wealth Even though a woman's husband's wealth did not clearly determine her lifetıme fertılity (above), lineage success could nonetheless be influenced Women born to rich fathers were more likely to marry at somewhat younger ages (above), and marry ncher men Their sons, likely to be richer themselves, had greater likelihood of fertility Thus, after a one-generation lag, lineage increase through daughters as well as sons may have been greater for rich men than for poor men Extrinsic factors interact with these patterns (shown as "regulators" in Fig 3), as in other studies (e g , Wrigley and Schofield's 1981 classic Population History of England, Low and Clarke in press) Thus here we have stratified all comparisons by decade and parish to analyze the influence of wealth. These patterns reflect the possible diversity, and show the likelihoods facing 
indıviduals in different categories Importantly, sımılar aggregate patterns can arıse from differıng underlyıng indıvidual-level patterns

\section{DISCUSSION}

\section{What, if Anything, has Changed Over Time?}

In 19th-century Sweden, life-patterns of survivorshıp, migration, and fertılity were clearly related to resources, wealth, and status Over their lives, both daughters and sons of wealthier men were lıkely to have more children than daughters and sons of poorer men, as a result of interactıng factors variously related to wealth. survivorshıp, lıkelıhood of becomıng wealthy in turn, and women's age at marriage This pattern remained true throughout the 19th century, including periods commonly designated as "demographic transition" As Figure 3 shows, father's wealth is certainly not all that matters some percentage of both sons and daughters of wealthier men fall to marry and have chıldren The most dramatıc pattern of chıldren's lives with father's wealth is that sons of poorer men, even in egalitarian 19th-century Sweden, had almost no chance of becomıng wealthy and having more than the median number of children (Fig. 3c)

Our results (also see Voland 1990, Turke 1989, 1990, Low 1989, 1990a, b) suggest that, even in relatively modern tımes, in Western societıes which are monogamous and attempt to be egalitarian, wealth differentials promote fertility differentials When resources become constricted, (e g., Low 1989), family reproductive differentials are likely to disappear Others also have found this generally to be true Individual patterns in such important items as age of marriage typically vary with resources (e $g$. Wall 1984, Sharpe 1990, Cain 1985; Mclnnıs 1977, Pfister 1989a,b; Thompson and Britton 1980 , Hayamı 1980; Schultz 1982, Simon 1974) Depending on theır own resource bases (e g , Galloway 1986, Schultz 1985), families may respond quite differently to such influences as market shifts, treat their children quite differently (c.g , Mittcraucr and Sicder 1982 110), even aggregate data tend to reflect resource influences as individuals make decisions (e $\mathrm{g}$, Thomas 1941; Wrigley 1983a,b)

Why then do so many studies of modern fertılity fall to find these patterns? We suggest several possibilities.

[1] Census data are not designed to elucidate information about family lineages, but households It is, for example, impossible to tell "own" children, from stepchildren, from other relatives living in the household from nonrelatives living in the household When actual lineage data are examined (e g , Mueller 1991), wealth and status are likely to be correlated with fertılity for men even today

[2] The existence of effective, cheap contraception is bound to complicate any relationshıp between wealth and fertılity (though we note that 
varıous forms of fertility limitation. including sex taboos, abortion, and infanticide are widespread in "natural fertility" populations, e g, see Campbell and Wood 1988, Low et al 1992) Pérusse (1992) examined copulation frequency in a modern, contraceptıve society, and found that wealth correlated with copulation frequency for men. even when number of children produced did not

[3] When offspring must compete for limited resources, parental shifts from production of offspring to investment in offspring (MacArthur and Wilson 1967, Rogers 1990, 1991) will be favored True parental investment, specific to particular offspring, must reduce the number of offspring, unless parental resources increase This will reduce the range, and possibly the variance, of reproductive success, though it need not reduce any correlation between fertılity and wealth

14] In the Swedish sample, wealth was men's wealth Today. much household income is earned by women As we have noted elsewhere (Low and Clarke in press), the effort which must be expended by women to earn money in market economies often represents a real conflict-a woman cannot do child care at work In traditional societıes, women could do a variety of tasks whıle doıng chıld care, and women could call on older daughters to help durıng much of the day (not after school) with child care (nonetheless, some conflicts exısted between work versus child-care requirements. Hurtado et al in press)

We cannot analyze the impact of the first two possibilities, but will discuss the third and fourth points here

\section{Reproductive Production vs Investment}

When resources are relatıvely ineffectıve in lowerıng chıldren's mortality or enhancing their competitive success, fertility will be high Such conditions obtain in many traditional societıes, and, we suspect, in a good many preand proto-industrial societies Wealth or status and reproductive success (at least among men) are positively correlated in many quite varied societıes (c g . Hill 1984) In the Turkmen. Irons (1979) found that richer men had more wives and more chıldren than poorer men Borgerhoff Mulder (1987, 1988) found that among the agricultural and pastoral Kıpsigıs, richer men produced more children than poorer men, the brideprice required for a woman was directly related to her reproductive value, so that richer men could afford younger wives with more reproductive potential With the introduction of western technology and medicine. differentials were reduced In the pastoral Mukogodo of Kenya, Cronk (1991) found that wealth enhances reproductive success for men, in his study he was able to show the direction of causalıty Simılarly, the Meru use livestock for bridewealth, and richer men can marry more wives (Fadiman 1982), much conflict occurs over cattle (and thus, ultımately, women) In societies as diverse as the Hausa (Barkow 1977). Trınidadians (Flınn 1986). and Micronesıan islanders 
(Turke and Betzig 1985), status and wealth correlate with male reproductıve success

In some traditional societies, such as the Ache (Kaplan and Hill 1985, Hill and Kaplan 1988) and the Yanomamo (Chagnon 1979, 1982, 1988), few physical resources are owned; even here, status represents a resource In the Yanomamo, male kın avallable for coalitions also represent a resource, and men manıpulate kınship terms in ways that make more women avalable for mates, and powerful men as coalition partners (Chagnon 1979, 1982), so that reproductive success is uneven Among the Yanomamo, not only being a member of a numerous and therefore powerful kın group works as a method of gainıng wives, but also gainıng recognition as a revenge-kıller (Chagnon 1988) In none of these cases was there a correlation between chıldren's survival and father's resources; the correlation existed between wealth/status and number of wives, and wives with their children were frequently relatively independent economic units

Our results have the clear implication that fertility declines, even today, are likely to be local, and locally reversible, rather than singular events with sıngular causes The extent to which we can predict fertılity shifts as a result of economic conditions or purchasing power will depend on a number of factors, but especially how much parental investment assists individual children. Perhaps the relatıve costs and benefits of chıldren themselves are influentıal (e g., Easterlın 1978, Becker and Barro 1988, Turke 1988) resource differentials, opportunitıes for better-educated children, and migration opportunities As resources begin to decrease, the risks of migration will be perceived as less onerous, we expect migration to increase if it can offer reproductively less successful individuals an alternatıve

Even the richest family's wealth could be dissipated through continued even investment in large numbers of children, thus unequal investment (even in the face of legal mandates for equal inheritance) are unsurprisingly common (e g , Hartung 1982, Low 1990a, Low et al. 1991) When increased investment in individual children enhances their ability to survive, marry, and reproduce, net lineage success can be enhanced by shiftıng more resources into investment in children (education, savings, health insurance, resource gifts, etc ); unless there is a net increase in total resources, the allocation of avalable resources must be into fewer children (e.g, Rogers 1990, 1991) This is true whether one considers cases in which investment enhances survivorshıp directly, or cases such as those proposed by Tilly (1978) in which survivorship shifts are considered to be exogenous

This ecological approach echoes some classic demographic modeis centered on "individual decision" and "proxımate variables" (e.g , Becker 1981, Becker and Lewıs 1974, Easterlın 1978. Tılly 1978, Bongaarts 1978, 1982, Lindert 1978, Simon 1974, Lesthaeghe and Wilson 1986), as well as Mosk's (1983) "leveragıng'" approach to fertılıty, and Easterlın and Crımmıns' (Crımmıns and Easterlın 1984; Easterlın and Crımmıns 1985) models of the factors favoring a shift to conscious control of fertility. All of these 
models have two important characteristics individuals are not assumed to be uniform, and there is an explicit trade-off between quantity and "quality" (probable success) of chıldren Such models have had a varıed fate in the literature

The conceptual advance of a behavioral ecological approach is this if we consider not only monetaly but reproductive, currencies, previously perplexing fertility patterns of some societies may become understandahle The perceived non-generality of some of the earlier models may be due not to flaws in the postulated relationships, but to the difficulties of trying to explain patterns partly based on reproductive "decisıons" by considering only the value of children in monetary (rather than lineage) currencies (cf Becker's work) Behavioral ecological models may, in fact, be very general, affecting all sexually-reproducing organısms, and not particular to one or another society, or one or another currency

There is a wealth of supportıng evidence from many bıological studies, that, while of course simplistic, may by useful in establishıng generality MacArthur and Wilson (1967 145-150) argued that, when the density of conspecific competitors (in any species) was low, selection favored "productıvity" and competitıve efficiency of off spring was relatıvely unımportant to their eventual success, in more competitive environments, selection favored the production of more competitive (better nourished, better taught) offspring-at the cost of number of offspring, parents should shunt resources into offspring investment, even at the expense of offspring numbers-net lifetıme reproduction was enhanced not by high fertılity, but by lowered fertılity_producing fewer but better-ınvested offspring

Following this logic, across human societies complexities in either the ecological or social environment which result in increased effectlveness of parental investment should result in more investment, at the expense of tertilty itself (see review by Low et al 1992) Thus, it is not surprising that wealth differentıals promote fertılity differentıals, even in Western societıes which are monogamous and attempt to be egalitarian As we noted above, this is true at the "high" end of the socioeconomic scale Rank (1989) found that at "low" socioeconomic levels, women on welfare have tewer children (age-specific fertility is lower at all ages) than women not on welfare, and that these welfare recipients specifically cited the need for resources to invest in their existing chıldren as the reason for avoiding further pregnancies

In human populations, male fertility typically increases with income within socioeconomic groups (above). For women, the conflict between investment capability and fertility is sharper than for men, even in traditional societies (e $\mathbf{g}$, the 'Kung women above) When monetary resources become central to children's success, women's shift from traditional maternal investment patterns to market employment typically has negative impact on fertılity (e $\mathrm{g}$, Farooq and DeGraff 1988, below) The link to industrialızation may simply be an example of a general phenomenon technological advances 
may require more education or traınıng (e g, Knodel et al 1990) and thus more investment to produce each competitive child. Such education (or other required skılls) is seldom free, thus we might expect fertility declines frequently to start among the rich (who have the most to invest in compet1(iveness, and as we noted above, typically the largest family sizes) Further, as Turke (1989) has noted, increased investment to enhance competitiveness hy even a few famılies will raise the stakes for all competing famılıes in the population Finally, Turke (1989) has argued that, as famıly and kınship networks are weakened (e.g, by spatıal disruption), fertılity will fall Older children and non-descendant relatıves ınitıally comprise a resource-nepotıstic effort When that resource declines, children pose an increased cost to their parents, a cost no longer defrayed by kin help Thus, fertılity will decline

\section{Wealth Among Nations, Men, and Women}

It seems to us important to ask, in each case, whether a child's eventual effectıveness in obtaınıng resources requires more (especially monetary) investment by parents in individual children, when it does, we predict fertility decline, but when it does not (many proto-industrialized and other labor markets using unskilled labor), we do not Thus, even though the general pattern reported is that across countries, as resources (measured as GNP) increase, fertility declines (Birdsall 1980), we suggest that within such societies or social groups, when men's fertility is considered, as resources increase, fertility should increase (Hughes 1988, Low and Clarke in press) That is, increasing GNP is in fact a correlate of cultural/technological/economic changes which result in a competitive requirement for increasing investment in individual children to ensure their success (Fig 4a) When considering women's earned income and their individual fertilitıes, a conflict exists, and women richer through their own efforts may have lower fertility than women married to wealthy men

Because families of different status, and even of different background (do current resources represent an increase or a decrease? ${ }^{?}$ ), may be differentially able to get and use resources equally, we may not always see welltuned responses that agree with external assessment of resources Sometımes, for example, a superficıal examınation suggests that men's fertılity decreases with wealth, even withın a society However, even when greater societal resources correlate with increased importance of investment in each child, and correlate with lowered fertility, we should not be surprised if men with relatively more resources withın each stratum of society have more children than men with fewer resources ( $\mathrm{F}_{1 \mathrm{~g}} 4 \mathrm{~b}$, see also Hughes 1988) In fact, Johnson and Lean (1985) review relevant studies, which suggest that couples assess their income relative both to their parents income in the pervious generation and to others in their social economic group (Low and Clarke in press) Similarly, Freedman and Thornton (1982) have shown that 

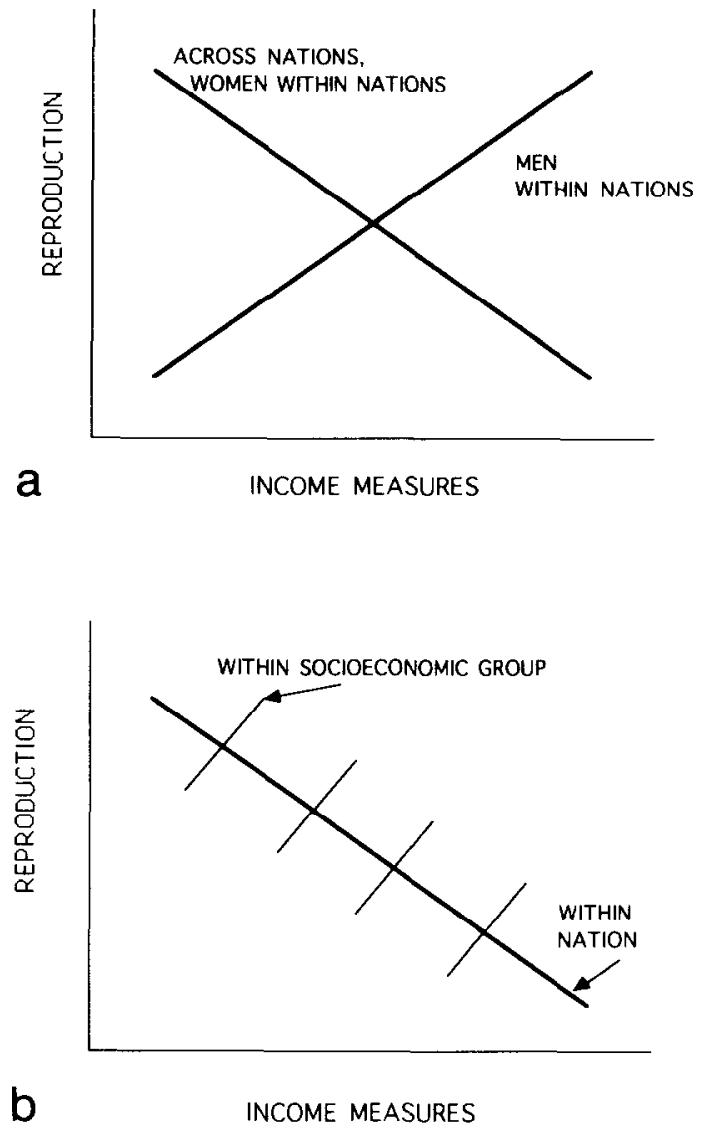

FIGURE 4 (d) As resources due to own work increases, we expect different tertility patterns for men (Increasing) versus women (decreasing) within a society Crossnational comparisons of aggregate fertilıty versus GNP typically look like the women's curve, and women's work and education may be important proximate fertility determınants (b) These patterns are further complicated by patterns withın socioeconomic groups in some modern societıes See text for further explanation

in the United States, families make deliberate decisions about family size in response to their judgment of avalable resources, and that, when deliberately chosen family sizes are considered, there is a correlation between income and family size When accidental pregnancies are considered, the picture becomes less clear Studies suggest that when income is judged as favorable relative to others, fertılity is increased (e $g$. Turke 1990)

Thus, investment level required to produce successful offspring may vary with environment, and specifically with the threshold level of investment required for a child's success-often a correlate of competition, and in this sense, precisely analogous to the proper use of MacArthur and Wilson's concept ( $r$ - and K-selection, see review by Low et al 1992) If poorer parents cannot substantially enhance their chıldren's success, then we might 
expect larger families, concentration of resources in one or a few children, with others living with the family or leaving early (behavioral ecologists would call this an "alternate strategies" situation) Couples at the high end of the socioeconomic "ladder" might do better by investing more per child to allow them to be competitive with their peers ( $\mathrm{g}$, education, clothıng, status acquisitions) The required investment may limit the number of children they can afford. Withın sub-groups, however, those with more than sufficient resources may be able to support additional children and still have all be adequately invested

Measuring "resources" is, of course, a difficult task. Important resources can differ significantly between and within regions These differences result not only from physical differences in the environment, but also from the social structure of the population Here we have used a simple combination of information about best status and landownershıp We have suggested that relationships between resources and reproductive patterns can be easily clouded by aggregate data and inadequate measures of total resources, and predictive analysis of population/environment interactions will depend on careful evaluation of variation in both physical and social environments

\section{CONCLUSIONS}

In summary, we suggest that resources positıvely influence lifetıme reproductive success both through production of and investment in children This relationship appears to hold, then, not only for traditional societies, but through the demographic transition in19th-century Sweden External conditions which influence competitiveness influence the relative potency of investment versus production Perhaps a re-examınation of existıng data in this broader, behavioral ecological, perspective would be useful For example, industrialization may not be, of itself, a force driving toward lower fertılity, unless success in an industrial environment requires greater traınıng or monetary investment by parents, resultıng in later marriage ages, and often, fewer children marryıng (e g, the "European" marriage pattern, Hajnal 1965) We also suggest that, if high fertility is not a response to infant loss (see Low et al 1991, Low 1991), medical and public health measures leadıng to increased infant survivorshıp, though warranted in their own right, will not, in themselves, lead to lowered fertulity What we should look for is any force enhancing the effectweness for net reproduction of increased investment in individual children ability to purchase medical scrvices, ability to will reproductively useful resources such as land or status (e.g, the heritable status of the British peerage, Hollingsworth 1957), investment in education, etc As parents' ability to influence their children's eventual success by investment increases, we expect fertility to decline, and resources to be routed into investment, decreasing mortality and increasıng success 
of children Thus, rather than "the" demographic transition with a singular cause, we expect fertılity trends with local, reversible, patterns In our data, as well in the work of others, we find that the primary components of population change (fertılity, mortalıty, and migratıon) respond to ecological conditions at the individual family level in ways that are predictable, and familiar to students of nonhuman populations In our 19th-century Swedish population, even during the demographic transitıon, resources are positively correlated with family sıze and lifetıme reproductıve success Resources make certain life-paths far more likely than others

We need not postulate a conscious decision on the actors' parts to predict these patterns True, our human consciousness offers us additional, perhaps less panful, options for responding. but it does not entirely free us of the constraints and opportunities which our environment provides Human complexity and conscious decision can (as many demographers and economists have subtly appreciated) add special dımensions For instance, we find that not just the amount of resources held, but also the economic liquidity of those resources, may influence an individual's success In a deterioratıng environment, a farmer's land may be less easily converted than alternative resources held by the upper-and lower-muddle class Then land. usually a valuable resource, may limit migration options (Clarke and Low in press)

In sum, we suggest that certain predıctable ecological rules underlie patterns of fertility, mortality. and migration, although these may be constraıned by a variety of cultural complexities and interactions For example, men's reproductive patterns vary in concert with resource control to a much greater extent than women's patterns, this variance between the sexes is greatest when resources are abundant When resources become constricted, reproductıve responses are uneven among famılies, and even withın familıes In a resource-constriction period, we might find very unequal investment in children within a family, with heightened investment in older (closer to successful reproduction) sons (whose success we predict to be more dependent on resources than daughters) We have published these findings previously (Low 1989, 1990a, 1991, Low and Clarke 1991 in press, Low et al 1992) Our argument converges on several demographic models, it differs in maintainıng that not primarıly financial, but genetıc lıneage (reproductıve) returns have shaped patterns of human fertility Different predictions arise, and can be tested, Indeed, e g , Boone (1986), Turke (1989, 1990), Borgerhoff Mulder (1988), Mueller (1991), Voland (1984, 1989, 1990), and Voland and Engel (1990) have begun just such tests

What happens to populations, we argue, is the statistical sum of what happens to individual lifetımes-and thus famıly fertilıty, survivorshıp, and mobility - as a result of familial resources and effectiveness of investment by parents in individual children If various kinds of families respond differently to external shifts in resources (perhaps because they have differential access to those resources, or because the shifts profit some while 
costıng others), then what happens to population numbers, and ultimately how the environment in its turn is affected by the population, depend on what proportion of the population comprise different kinds of families If we fall to measure the appropriate resources, or if we look simply at aggregate measures or only for conscious decisıons as mediators, we may make the wrong predictions and set inappropriate polıcies

We gratefully acknowledge the help of the Swedish Demographic Database, especially Gun Stenflo and Anders Brandstrom, in garnering and checking the data Dr R Ostergren. University of Wisconsın, graciously shared mantal (land ownershıp) information he gathered for other research Funding was provided by Provost Bılly Frye the American Phılosophıcal Society, the American Scandinavian Foundation, and a United Nations and MacArthur Interdisciplınary grant for the Unıversity of Michigan Populatıon-Environment Dynamics Project Ken Lockridge (Unıversity of Montana) and Jan Sundin (Linkoping Unıversity) provided valuable historical perspective Regina Baker assisted with statistıcal problems The Cambridge Populatıon Group was most cordial and supportıve in discussıon and in makıng reference material avaılable A E Wrigley of the Cambridge Population Group, and John Caldwell of Australian National University, provided helpful critıcism Comments made by John Knodel, University of Michıgan, on another manuscript, were helpful Finally. Paul Turke, Laura Betzıg. Martın Daly. Margo Wilson, Bob Smuts, and the members of the Evolution and Human Behavior Program of the University of Michigan provided invaluable discussion

\section{REFERENCES}

Barkow, J H Conformity to ethos and reproductıve success in two Hausa communtıes An empirical evaluation Ethos 5 409-425 1977

Becker, G A Treatise On The Familv, Cambridge Harvard Universty Press 1981

- and Barro. R J Reformulating the economic theory of fertility Quarterly Journal of Ec $O$ nomics $103 \quad 1-25,1988$

- and Lewis, H G Interaction between quantity and quality of chıldren In Economic s of the Familv Marriage. Children and Human Captial. T W Schultz (Ed) Chicago Chicago University Press, 1974, pp 81-90

Betzig. L L Despotism and Differential Repioduction A Dam untan Vlew of Historv, Chicago Aldine Press, 1986

Birdsall, N Population growth and poverty in the developing world Population Bulletin 35(5) $3-46,1980$

Blurton Jones $\mathrm{N}$ Bushman birth spacing a test for optımal interbirth intervals Ethologv and Sociobiologv 7 91-105, 1986

- Bushman birth spacing Direct tests of some simple predictions Ethologv and Sociobiology $8 \quad 183-203,1987$

- The costs of children and the adaptıve schedulıng of births towards a sociobiological perspective on demography In Sexual and Reproduche Strategles A Rasa, C Vogel, and E Voland (Eds) Kent Croom Helm, 1989

Bongaarts, J A framework for analyzing the proximate determinants of fertılity Population and Development Review' 4(1) 105-132, 1978

- The fertılity inhibiting effects of the intermediate fertility variables Studies in Famiv Planning 13(6/7) 179-189. 1982

Boone. James $L$ III Parental investment and elite family structure in preindustrial states A case study of late medieval-early modern Portuguese genealogies American Anthopologest 88859,1986

Borgerhoff Mulder, $M$ On cultural and bıological success Kipsigis evidence Americ an Anthropologist $89 \quad 617-634.1987$ 
- Kipsigis bridewealth payments In Human Reproductue Behationa A Darniman Perspectu'e $\mathrm{L}$ Betzig $\mathrm{M}$ Borgerhoff Mulder and $\mathrm{P}$ Turke (Eds) Cambridge Cambridge University Press, 1988, pp 65-82

Brandstrom, A De Karlekslosa modrarna Spadbarnsdodlighetenı Sverıge under 1800-talet med sarskıld hansyn tull Nedertorned Acta Unuersulats Umensts $62 \quad 1-2711984$

- The silent sick Life histories of 19th century Swedish hospital patients Socten. Health and Population daing the Demographic Tiansition, A Branditrom and L. -G Tedebrand, (Eds) Demographic Database Umeå Sweden Stockholm Almqvist and Wiksell International 1988 Report No 4 pp $343-368$

Cain. M On the relationshıp between landholding and fertulity Populatom Studies $395-15$ 1985

Campbell, K L and Wood, J W Fertility in traditional societies In Nanual Human Feitulin Soctal and Biological Determinants P Diggory $\mathrm{M}$ Potts and S Teper (Eds) London Macmillan Press, in cooperation with The Eugenics Society 1988 pp 39-69

Carlsson. S Froknar mamseller Jungfril och pigor Ogifta himnol det rensha stindsamhallet, Uppsala, 1977

Chagnon. N A Is reproductive success equal in egalitarian societies' In Eirolutionan Biologs and Human Socal Behaiol An Anthropological Perspective N A Chagnon and W Irons (Eds) Boston Duxbury 1979

- Sociodemographic attributes of nepotism in tribal populations Man the rule-breake in Cuirent Problems in Sociobologr Kings College Sociobiology Group (Eds) Cambridge Cambridge University Press 1982

- Life histones, blood revenge and wartare in a tribal population Sctence $239985-992$ 1988

Clarke, A L and Low, B S Ecological Corselates of Dispes sal in Nineteenth Century Sweden Anmmal Behaitoul 1991 in press

Coale. Ansley J The decline of fertility in Europe since the eighteenth century as a chapter in human demographic history In The Decline of Feitilit in Eimope A Codle and S Watkins (Eds) Princeton Punceton University Press 1986 pp 1-31

Crimmins, E M, and Easterlın, R A The estimation of natual tertility A micro approach Soctal Bologv $31 \quad$ 160-170 1984

Cronk $\mathrm{L}$ Wealth status and reproductive success among the Mukogodo of Kenva Ameman Anthopologist 93(2) 345-360 1991

Daly $M$ and Wilson, $M$ Set Evolition and Behatum Ind edition Boston Willard Grant Press 1983

Darwin C The Descent of Man and Selectom an Relation to Sel 2 volumes London John Murray, 1871

Dawkins R The Evended Phenotipe The (senc as the Unt of Selectum Oxtord W H Freeman 1982

- The Blind Watchmake' New York Norton 1986

- The Selfish Gene New Edition Oxford Oxtord Universty Press 1989

Easterlin R The economics and sociology of teitility A synthess In Historical Studics of Changing Fetalit) ( Tilly (Ed) Princeton Princeton Universty Pien 1978 p 57134

- Alter G and Condran G A Farms and tarm tamilies in old and new areas The nos thein

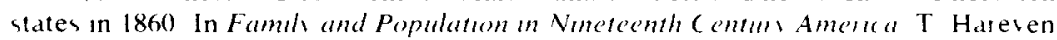
and M Vinovskis (teds) Pinceton Princeton University Piess 1978

- and Crimmins, E The Fellihi Revolutom A Supph-Demand Anahs (hicago Universily of Chicdgo Press 1985

Fadiman I A An Oral Heston of Thbal Watale The Menu of Mt Kema Athens OH Ohio Unuver sity Press 1982

Falconer DS Introdurtom to Quantitame Genetic, 2nd edition 1 ondon and Neu York Longman 1981

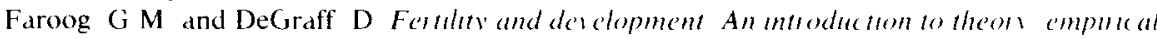
reseak h and polke wsues World Employment Progiamme Backgound Papers tor Tranıng in Population Human Resources and Development Tranıng No 71988

Fisher R A 7he cenetical Theor of Natual Selection 2nd edituon Neu York Dovel 1958

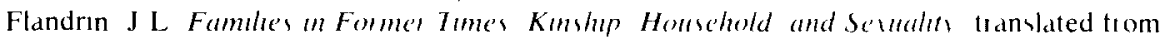
the Fiench by R Southein Cambridge Cambridge Universlly Piess 1979 
Flınn, M V Correlates of reproduction success in a Caribbean village Human Ecologi 14 225-243. 1986

- and Low, B S Resource distribution, social competition, and mating patterns in human societıes In Ecologkal A spects of Soctal Evolıtuon. D Rubenstein and R Wrangham (Eds) Princeton Princeton University Press 1986 Chapter 11

Freedman. D S and Thornton. A Income and fertility the elusive relationship Demogiaphv 19(1) $65-78,1982$

Galloway, P R Differentıals in demographic responses to annual price variations in prerevolutıonary France A comparison of nch and poor areas in Rouen. 1681-1787 European Joun nal of Population 2 269-305, 1986

Gaunt, D I slottets Skugga Om frallse-bonders sociala problem I Borgeby och Loddekoppınge under 1700-talet Ale 15-30, 1977

- The property and kın relations of retıred farmers In Familv Fomms in Hatomu Europe R Wall, J Robın, and P Laslett (Eds) Cambridge Cambridge University Press, 1983

- Rural household organization and inheritance in Northern Europe Jommal of Familv Histolv $12121-141,1987$

Gerger, T and Hoppe, G Education and society The geographer"s view Acta Universtatrs Stockholmensis I 1-124, 1980

Habakkuk, H J Famıly structure and economic change in nineteenth-century Europe Journal of Economic Histol, $15 \quad$ 1-12, 1955

Hajnal, J European marriage patterns in perspective In Population in Historv Essavs in Histork al Demographv, D V Glass and D E C Eversley (Eds) London Edward Arnold Publishers, 1965

Hammel, E A , Johansson, S , and Gunsberg, C The value of children during industrialization Sex ratios in childhood in nineteenth-century America Joulanal of Familv Historv Winter 400-417, 1983

Handwerker, W P Culture and reproduction Explonng micro/macro linkages In Cultule and Repioduction An Anthopological Cittique of Demogiaphic Transition Theorı. W P Handwerker (Ed) Boulder Westview Press 1986

Hartung. J Polygyny and inheritance of wealth Cwient Anthopologv $23 \quad$ 1-12, 1982

Hayamı, A Class differences in marrıge and fertılıty among Tokugawa villagers in Mıno Province Keto Economic Studies 17(1) 1-16 1980

Hıll, J Prestıge and reproductive success in man Ethologv and Soctoblologi 5 77-95 1984

Hill, $\mathrm{K}$ and Kaplan, $\mathrm{H}$ Tradeoffs in male and female reproductive strategies among the Ache In Haman Reprodactwe Behavoun A Damman Perpeatue L Betzig M Borgerhoff Mulder, and P W I urke (teds) Cambridge Cambridge Universty Press, 1988 Part I pp 277-289

Hollingsworth, T H A demographic study of the British ducal tamilies Population Studies XI(I) 4-26 1957

Hughes A L Reproductive success and occupational class in eighteenth-century Lancashire England Soc al Bology 33 109-115. 1986

- Evelation and Haman Kinship Oxford Unversity Press, Oxtord, 1988

Hurtado $\mathbf{M}$ Hıll K Kaplan $\mathbf{H}$, and Hurtado I Tradeoffs between food acquisition and child care among Hiwı and Ache women Human Natule, in press

Inger, $G$ Siensh Ratshustoula, Liber Laromedel 1980

Irons W Cultural and biological success In Eiolutonam Btologi and Human Sor tal Behat ion An Anthopologucal Pespectue. N A Chagnon and W Irons (Eds) North Scitude MA Duxbury Press, 1979

Johnson NE and Lean S Relative Income Race, and Fertulity Population Studies 39 991121985

Jorberg L A Histony of Prices in Sueden 1732-19/4 2 volumes Lund CWK Gleerup. 1972

- Structural change and economic growth in nineteenth-century Sweden In Sicden's deletopment fiom poient to affluence 1750-1970. S Koblık (Ed) Minneapolis Unıversity of Mınnesold Press. 1975. pp 92-135

Kaplan $H$ and Hill, $K$ Huntıng ability and reproductive success among male Ache foragers Preliminary results (ument Anthoplogv 26 131-133, 1985

Keyfitz Nathan Applied Mathematical Demogiaph 2ndeditıon New York Springer-Verlag, 1985 
Knodel J Havanon, $\mathrm{N}$ and Sittitraı, W Family stze and the education of children in the context of rapid fertility decline Population and Detelopment Reiten 16(1) 31-62 1990

Krebs, J R and Daves N B Behavomal Loologs An Lolutonal Appoach ird edition. Sunderland MA Sinauer 1991

Lack D The significance of clutch s1/e $I h /$ s $89 \quad 302-3521947$

- Populaton Studes of Buds Oxtord (latendon Press 1966

Lesthaeghe $\mathrm{R}$ and Wilson ( Modes of production secularization and the pace of the fertility decline in western turope $1870-1930$ In 7 he Declue of Foulth in Europe A J Coale and S Watkins(teds) Princeton Princeton Unviersity Press 1986

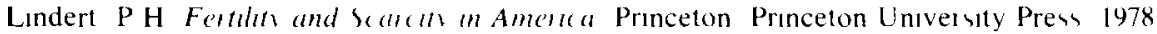

Lithell U-B Poverty and mantal tertility a low standard of living as a determinant of a low level of marital tetulitv and a high intant mortality In Marlage and Femulan Local Pattems in Pie-mindstial Sueden Finland and Nom the Family Histolv Group Department of History University of Uppasa 1982 No 3 pp 67-95

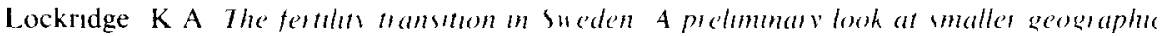
unus 1855-1890 Demographic Database Umed University Repont 3 1-135 1983

Lo-Johannson F Srenges Rikes Lag Gilladoch Antagen Pamdagen Al 17.34 fahsmulareara Matmo Giulunds 1981

Low B S Occupational status and reproductive behaviot in nineteenth-century Sweden Locknevi Parish Social Bologv $36 \quad 82-1011989$

- Occupdtional status landownership and reproductuve hehavior in nineteenth-centur Sweden I und Parish Amertan Anthopologet 92 457-468 1990a

- Sex power and resources ecological and social correlates of sex differences Imemathonal Jounal of Contemporaly Soctologr $2749-73 \quad 1990 \mathrm{~b}$

- Reproductive life in mineteenth centurv Sueden An evolutionary perspective on demographic phenomena thologi and Socobologe 12 411-448 1991

- and Clarke A I. Family patterns in 19th centurs Sueden Impact of occupational status and landow nership Jommal of $I$ amh $H a t a m$ 16(2) 117-138 1991

- and - Historical perspectives on population and environment Data from 19th century Sweden In Population-Enuonment Dinamu, Idoas and Obremanom, G Ness W Diake and $\mathrm{S}$ Biechen (Eds) Ann Arbol University of Michigan Press in piess

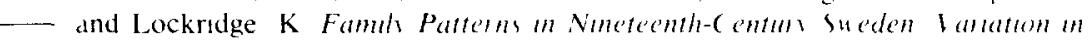
Time and Space' Demographic Dalabase Monograph No 6 Umea Sueden 1991

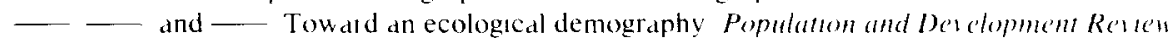
18(1) $1-31 \quad 1992$

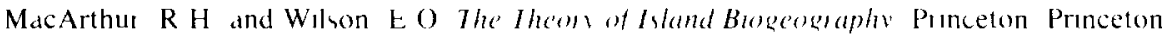
University Press 1967

Malmstrom A Succesumuatl II Uppala lustuus Forlag 1981

Mcinnis R M Childbearing and land avalability Some evidence fiom individual household data In Population Patoins an the Past R Lee (Ld) New York Academic Press 1977 pp 201-227

Mendels FF Industrialization and population pressute in eighteenth-centus Flanders Neu York Arno Piess 1981

Mitterauer M and Sieder R Ihe Emopean Famih Oxtord Blackwell 1982

Mosk C PatnanchandFemha Japanand Sweden 1880-1960 Neu Yosk Academu Piess 1983

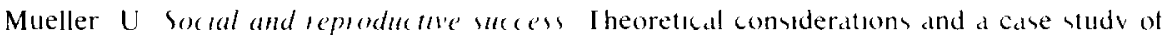
the West Pount Class of 1950 ZUMA Zentıum fur Umfragen Methoden und Analysen 1991

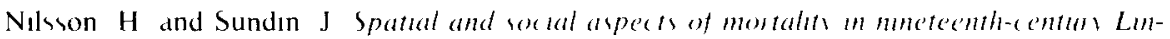
hopme and as hmoland Paper presented to the foth Annual meeting of the Socid! Science History Association New Oileans 1991

Norberg $A$ and Rolen $M$ Migration and mallage Some empincal results trom Tuna parish 1865-1894 In Time Space and Man Essys on Miciodemography I Sundin and $E$. Soderlund (Ed,) Stockholm Almquist and Wiksell 1979

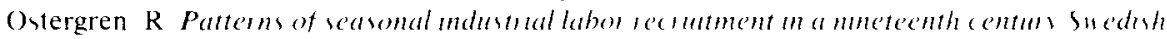


partsh The case of Matfons and Tuna 1846-1873 Demographic Data Base Report No $5 \quad 1-100 \quad 1990$

Pérusse D Cultural and ieprodur the surcess en industral socteties Testing the colationshup at proxmate and ultumate levels Behatroral and Bian Sciences 1992

Pfister, U Proto-industrialization and demographic change the Canton of Zurich revisited Jout nal of Economic Hotom $18 \quad 629-6621989$ d

- Work roles and tamily structure in proto-industrial Zurich Jounal of Interdesciplinar Histor $2083-1051989 \mathrm{~b}$

Rank, M A Fertility among women on welfare Incidence and determinants Amencan Soc $l^{-}$ ological Revien $54 \quad 296-3041989$

Rogers A R The evolutionary economics of human reproduction thologv and Soc lobologv $11479-495,1990$

- Conserving resources for children Human Natue 2(1) 73-82 1991

Schultz T P Family composaton and income incqualit Yale University Economic Growth Center Paper No 251982

- Changing world prices women s wages and the fertility transition Sweden, 1860-1910 Jounal of Pollic al Economv 9316) 1126-1154. 1985

Sharpe $\mathrm{P}$ The total reconstitution method A tool for class-specific study" Loc al Population Studies $44 \quad 41-51 \quad 1990$

Simon J The effecrs of income on teitiln Carolina Population Center Monograph No 19 Chapel Hill, North Carolina 1974

Sundın, J Thett and penury in Sweden 1830-1920 A comparatıve study at the county level Scandinavan Joumal of Histon I 265-292 1976

- Family building in paternalistic proto-industries A cohort study from nineteenth-century Swedish iron foundries Jounal Famh Histow 14(3) 265-289. 1989

— and Tedebrand L -G Mortality and morbidity in Swedish iron foundries 1750-1875 In Traditonal and Transition Studies in Miciodemogiaph and Socual Change, A Brandstrom and J Sundın (Eds) Umeă Demographic Database University of Umea 1981

Thomas D S Soctal and Economic Aspects of Suedsh Population Morement, 1750-1933 New York Macmillan 1941

Thompson $\mathrm{J}$ and Britton, $\mathrm{M}$ Some socioeconomic ditferentials in fertility in England and Wales In Demographic Pattems in Dereloped Soctetes R W Hiorus (Ed) London Taylor and Franc1, 1980, pp 1-10

Tilly C The historical study of vital processes In Hotomical Stude's of Changing Fentilu, C Tilly (Ed) Princeton Princeton University Press 1978 pp $1-5.5$

Turke, P W Helper at the nest Childcare networks in Italuk In Human Reproductue Behaviou A Daminan Perspectue, L Betzig M Borgerhoff Mulder, and P I urke (Eds) Cambridge Cambridge University Press 1988

- Evolution and the demand for children Population and Developmkent Review $15(1)$ 61901989

- Which humans behave adaptively and why does it matter' Ethology and Soctobologl $11305-339.1990$

- and Betzig. L L Those who can do Wealth, status and reproductive successon Ifaluk Ethologr and Soctoblologi $6 \quad 79-87 \quad 1985$

Viazzo P P Upland Commumties Emuonment Populaton and Social Stulutue th the Alps sunce the Suteenth Centur. Cambridge Cambridge University Press 1990

Voland, E Human sex-ratio manıpulation Historical data from a German parish Joul nal of Human Evolution $1399-107 \quad 1984$

Differential parental investment Some ideas on the contact ared of Europedn social history and evolutionary biology In Comparatre Soctoecologi The Beharomal Ecologi of Humans and Otiner Mammals V Standen and R A Foley (Eds) Special Publication No 8 of The British Ecological Society, 1989 pp 391-402

Differential reproductive success within the Krummhorn population (Germany, 18th and 19th centuries) Beharloral Ecologi and Socloblologv $26 \quad 65-72 \quad 1990$

- and Engel C Female choice in humans a conditional mate selection strategy of the Krummhorn women (Germany, 1720-1874) Ethologi 84 144-154, 1990

Wall, R Real property marriage and children The evidence from four pre-industrial com- 
munities In Land Kinshup, and the Lite-Cucle R M Smith (Ed) Cambidge Cambridge University Press 1984 pp 443-479

Willams G C Adaptation and Natual Seledtom Princeton Princeton University Press 1966 Wrigley $E$ A The growth of population in eighteenth-century England A conundrum resolved Past and Piesent 98 121-150 1983a

- Malthus's model of a pre-industral economy In Malthus Past and Piesent J Dupaquer A Fauve-Chamoux and E Grebentk (Eds) New York Academic Press 1983b pp $111-124$

- The fall of marital tertility in nineteenth-century France Exemplar or exception' $E u^{-}$ opean Journal of Population I 31-60 1985a Part I

- The fall of marital fertility in meteenth-centurv Fiance Exempla or exception ' $L{ }^{-}$ iopean Jotinal of Population I 141-177 1985b Patt II

- and Schofield R S Tho Populatum Hotomt of Litgland. 154I-187/ Cambridge Harvard University Press 1981 